\title{
Analisa Stabilitas Pada Lereng Tambang Terbuka Lapangan "TG"
}

\author{
Robi Alfaq Abdillah, Moh. Singgih P, dan Dwa Desa W \\ Departemen Teknik Geofisika, Fakultas Teknik Sipil dan Perencanaan, Institut Teknologi Sepuluh Nopember (ITS) \\ e-mail:dwa_desa@geofisika.its.ac.id
}

\begin{abstract}
Abstrak-Sebagian besar eksploitasi batubara menggunakan sistem open pit, yang akan membentuk suatu cekungan. Cekungan hasil dari eksploitas mempunyai lereng. Kestabilan dari lereng pembentuk cekungan sangat penting karena menyangkut keselamat pekerja, alat, serta kelancaran produksi. Penelitian ini dilakukan untuk melakukan analisa stabilitas pada lereng tambang dengan menggunakan metode Bishope dan Metode Spencer. Analisa stabilitas dilakukan pada 7 model geometri. Dari ketujuh model masing-masing mempunyai nilai faktor keamanan dengan menggunakan metode bishop $\mathbf{0 . 6 4 3}$, $0.669,1.086,0.862,1.58,1.184$, dan 1.428. Nilai faktor keamanan dengan menggunakan metode spencer masing-masing $\mathbf{0 . 6 5 3}$, 0.695, 1.113, 0.893, 1.602, 1.208, dan 1.446.
\end{abstract}

Kata Kunci-Faktor Keamanan, Lereng Tambang Terbuka, Metode Bishop, Metode Spencer.

\section{PENDAHULUAN}

$\mathrm{T}$ AMBANG terbuka atau open pit mining merupakan salah satu cara yang dapat digunakan guna kepentingan eksploitas endapan mineral atau bijih. Proses penambangan dengan menggunakan sistem open pit akan membentuk suatu cekungan [1].

Kemantapan (stabilitas) lereng merupakan suatu faktor yang penting, karena menyangkut persoalan keselamatan manusia (pekerja), keamanan peralatan, serta kelancaran produksi. Apabila lereng-lereng yang terbentuk sebagai akibat dari proses penambangan (pit slope) maupun yang merupakan sarana penunjang operasi penambangan (seperti bendungan dan jalan) tidak stabil, maka akan mengganggu kegiatan produksi [2].

Mengingat pentingnya analisa stabilitas pada suatu lereng tambang maka disusun penelitian ini dengan tujuan mendapatkan nilai faktor keamanan suatu lereng tambang. Analisa stabilitas dilakukan pada tujuh model geometri lereng. Analisa stabilitas dilakukan pada lereng normal yaitu tidak ada gangguan dari faktor luar.

\section{TINJAUAN PUSTAKA}

\section{A. Daerah Penelitian}

Jika dilihat secara fisografis daerah penelitian terbagi atas empat bagian, Cekungan Sumatera Selatan, Bukit barisan dan Tinggian lampung, Cekungan Bengkulu (meliputi lepas pantai antara daratan Sumatera dan rangkaian pulau-pulau di sebelah barat Sumatera), serta Rangkaian kepulauan (fore arc ridge) di sebelah barat Sumatera, yang membentuk suatu busur tak bergunung-api. Cekungan batubara pada daerah penelitian tergolong dalam jenis cekungan paparan, karena berhubungan dengan kerak benua pada semua sisinya [3].
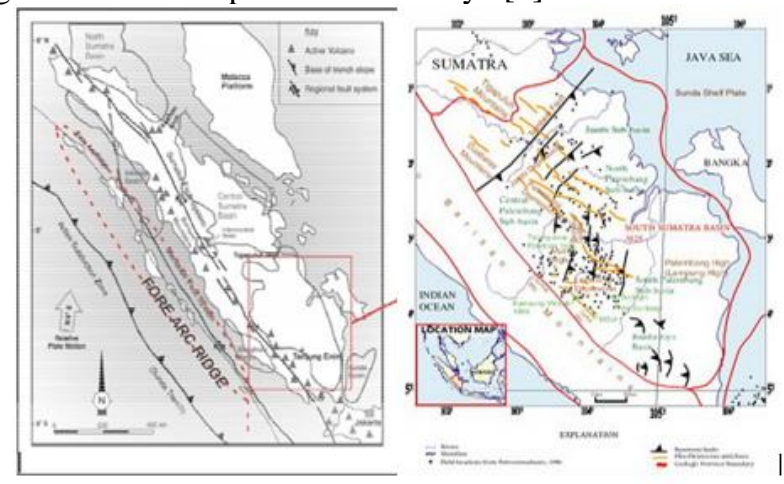

Gambar 1. Fisiografi Cekungan Sumatera Selatan [4]

\section{B. Analisa Stabilitas}

Dalam melakukan analisa stabilitas lereng terdapat dua kelompok besar, yakni, prosedur massa dan metoda irisan. Prosedur massa menggunakan analisis dengan cara massa tanah yang berada di atas bidang gelincir diambil sebagai satu kesatuan. Prosedur ini berguna bila tanah yang membentuk lereng dianggap homogen. Sedangakan metoda irisan, Pada cara analisis ini tanah yang ada di atas bidang gelincir dibagi menjadi beberapa irisan-irisan parallel tegak. Stabilitas dari tiap-tiap irisan dihitung secara terpisah. Metode ini lebih teliti karena tanah yang tidak homogen dapat juga dimasukkan dalam perhitungan [5]. Lereng yang terbentuk dalam penelitian ini merupakan lereng heterogen, sehingga lebih teliti jika menggunakan metode irisan. Metode irisan terbagi menjadi metode Fellenius, metode Bishop, metode Spencer, metode Janbu, dan metode Morgenstern \& Price. Pada penelitian ini digunakan dua metode yaitu metode Bishop dan metode Spencer.

\section{1) Metode Bishop}

Metode bishop mengasumsikan bahwa gaya-gaya antar segmen diabaikan, serta gaya normal yang terdapat pada dasar segmen dihasilkan dari menguraikan gaya-gaya pada segmen yang berarah vertikal. Kesalahan dapat terjadi jika bagian permukaan bidan longsor mempunyai lereng yang curam dan negatif di dekat kaki(toe). Metode Bishop meskipun termasuk kedalam metode yang sederhana tetapi mempunyai nilai keakurasian yang bagus terutama pada bidang longsoran berbentuk lingkaran [6]. Nilai faktor keamanan dengan menggunakan metode bishop dapat dihitungan dengan persamaan: 
$\mathrm{F} K=\frac{\sum \frac{1}{m}\left(c^{t} l+(W-\mu l) \tan \emptyset^{t}\right)}{W \sin \alpha}$

2) Metode Spencer

Metode Spencer sebenarnya mempunyai kesamaan dengan metode Morgenstern \& Price. Pada awalnya metode Spencer dibuat untuk analisa stabilitas pada bidang berbentuk lingkaran, namun seiring berjalannya waktu dapat diadaptasikan kedalam bentuk bukan lingkaran. Gaya-gaya antar segmen diasumsikan nilainya sejajar. Keakurat dari metode ini dapat diterima baik untuk analisa kesetimbangan gaya dan kesetimbangan momen.

\section{Kemantapan Lereng}

Terdapat beberapa standard yang mengartikan nilai faktor keamanan. Dalam penelitian pengartian nilai dari faktor keamaan menggunakan dua refrensi yaitu berdasarkan bowles dan berdasarkan SKBI-2.3.06,1987. Bowles memberikan makna terhadap nilai faktor keamanan seperti pada tabel 1.

Tabel 1.

Nilai F dan maknanya (Bowles 1989)

\begin{tabular}{ccc}
\hline \hline $\begin{array}{c}\text { Nilai Faktor } \\
\text { Keamanan }\end{array}$ & Makna Lereng & Kejadian Pada Lereng \\
\hline $\mathrm{F}>1,25$ & Relatif Stabil & Jarang Longsor \\
$1,25<\mathrm{F}<1,07$ & Kritis & Pernah Longsor \\
$\mathrm{F}<1,07$ & Labil & Sering Longsor \\
\hline \hline
\end{tabular}

SKBI-2.3.06,1987 memberikan nilai 1,5 sebagai standar untuk angka keamanan.

\section{METODOLOGI PENELITIAN}

\section{A. Data}

Data-data yang digunakan dalam penelitian yakni, data parameter mekanik tanah.

Tabel 2.

Parameter Mekanik Tanah

\begin{tabular}{lrrr}
\hline \hline \multicolumn{1}{c}{ Stratigrafi } & $\begin{array}{c}\text { angle internal } \\
\text { friction }\end{array}$ & Density & \multicolumn{1}{c}{ Kohesi } \\
\hline Overburden A1 & 17.91 & 18.92751 & 45.11059 \\
Seam A1 & 22.41 & 11.86647 & 85.6120545 \\
Interburden A1-A2 & 14.6 & 17.35839 & 49.03325 \\
Seam A2 & 0.398 & 11.86647 & 39.030467 \\
Interburden A2-B1 & 14.46 & 18.82944 & 46.091255 \\
Seam B1 & 34.26 & 11.47419 & 136.312435 \\
Interburden B1-B2 & 15.15 & 20.49663 & 17.65197 \\
Seam B2 & 27.47 & 11.67033 & 86.29852 \\
Interburden B2-C & 19.58 & 20.5947 & 20.5947 \\
Seam C & 23 & 11.47419 & 100.02783 \\
Under C & 19.43 & 19.614 & 51.975245 \\
\hline \hline
\end{tabular}

\section{B. Diagram Alir}

Penelitian ini dilakukan sesuai dengan alur penelitian seperti pada Gambar 2.

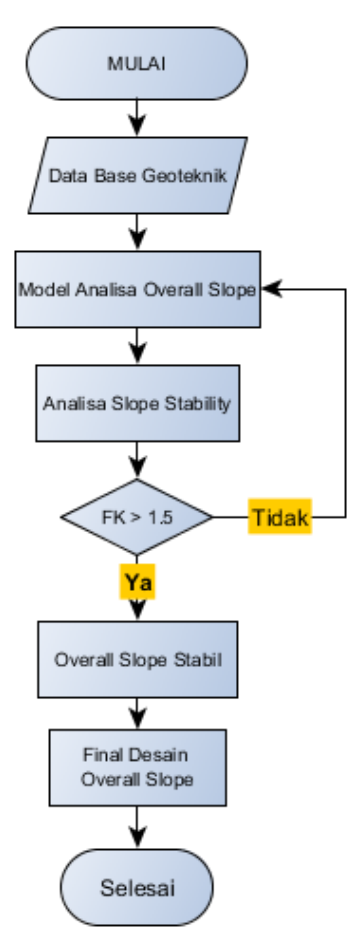

Gambar 2. Diagram Alir Penelitian

\section{HASIL DAN PEMBAHASAN}

Analisa stabilitas digunakan untuk mendapatkan geometri yang sesuai dan stabil. Geometri tersebut nantinya dapat digunakan sebagai landasan untuk membuat lereng, sebagai proses eksploitasi dari endapan batubara. Yang menjadi masalah adalah hasil dari pengolahan terkadang tidak sesuai dengan kenyataan yang ada. Oleh karena itu, pada analisa stabilitas lereng dengan menggunakan software harus dilakukan tidak hanya dengan satu metode analisis, supaya hasil yang diperoleh lebih terpecaya.

Berdasarkan dari analisa stabilitas yang dilakukan diperoleh nilai kritis dari faktor keamanan pada masing-masing model.

Tabel 2.

Hasil Analisa Stabilitas

\begin{tabular}{rrrr}
\hline \hline \multirow{2}{*}{$\begin{array}{c}\text { Model } \\
\text { ke- }\end{array}$} & \multirow{2}{*}{$\begin{array}{c}\text { Sudut } \\
\left({ }^{0}\right)\end{array}$} & \multicolumn{2}{c}{ FK kritis } \\
\cline { 3 - 5 } & 44 & Bishop & Spencer \\
\hline 1 & 42 & 0.643 & 0.653 \\
2 & & 0.669 & 0.695 \\
3 & 31 & 1.086 & 1.113 \\
4 & 38 & 0.862 & 0.893 \\
5 & 23 & 1.58 & 1.602 \\
6 & 28 & 1.184 & 1.208 \\
7 & 24 & 1.428 & 1.446 \\
\hline \hline
\end{tabular}

Berdasarkan hasil analisa pada tabel 2 dan refrensi pada tabel 1 maka diperoleh model geometri lereng yang memenuhi syarat kestabilan yaitu pada model geometri kelima dan ke tujuh. Akan tetapi, jika dilihat pada regulasi dari badan pengawas dan SKBI maka model geometri yang lebih memenuhi standard adalah model kelima. 
Pada model geometri kelima kedua metode yang digunakan menghasilkan nilai diatas 1,5 sehingga dapat dikatakan bahwa lereng tersebut mempunyai kerentanan terhadap terjadinya tanah longsor sangat kecil.

\section{KESIMPULAN/RINGKASAN}

Berdasarkan hasil analisa stabilitas didapatkan model geometri yang memenuhi syarat kestabilan dengan sudut overall slope $23^{0}$ dengan nilai faktor keamanan 1,58(Bishop) dan 1,602(Spencer).

\section{LAMPIRAN}

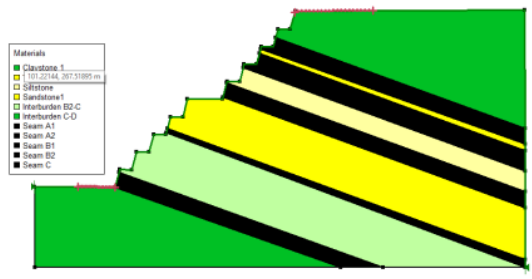

Gambar 3. Model Geometri 1

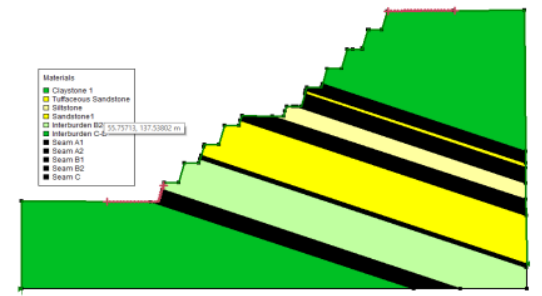

Gambar 4. Model geometri 2

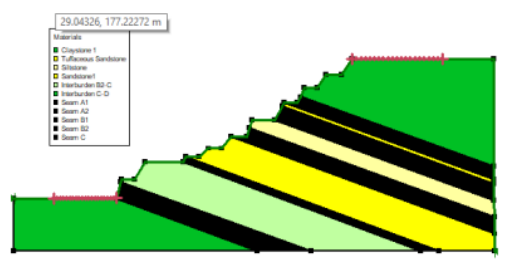

Gambar 5. Model Geometri 3

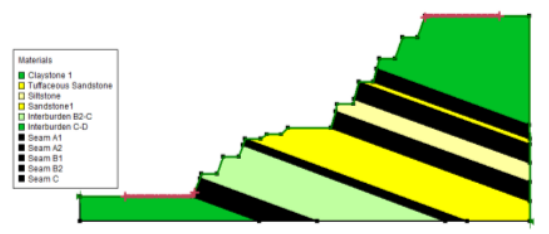

Gambar 6. Model Geometri 4

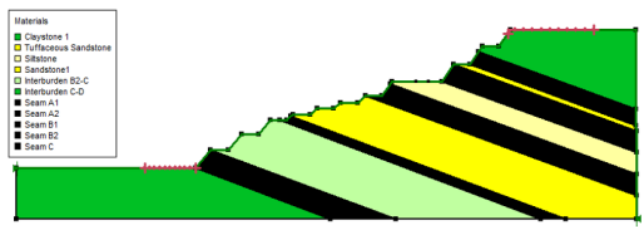

Gambar 7. Model Geometri 5

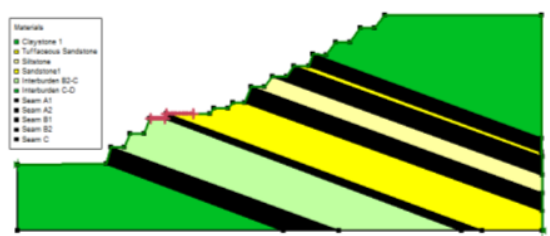

Gambar 8. Model Geometri 6

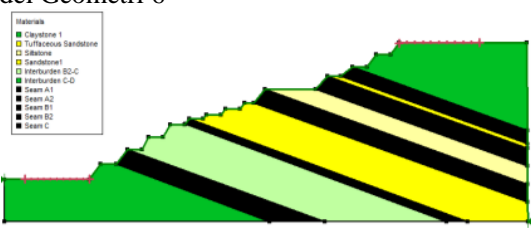

Gambar 9. Model Geometri 7

\section{DAFTAR PUSTAKA}

[1] J. and P. S. Read, OPEN PIT SLOPE DESIGN. Australia: CSIRO, 2010.

[2] Y. B. T. Gautama, R. S dan Pramono, "Kemantapan Lereng di Pertambangan Indonesia," ITB Bandung, 1991.

[3] R. P. Koesoemadinata, "Sedimentary Framework of Tertiary Coal Basins of Indonesia," in Proceeding of the 3rd Regional Confrencee on Geology and Mineral Resource of Southeast Asia (Bangkok), 1978, pp. 21-39.

[4] C. . Huticson, South-East Asian Oil, Gas, Coal, and Mineral Deposits. Oxford: Clarendon press, 1996.

[5] B. M. Das, Principles of Geotechnical Engineering. United State of America: Wadswoth Group, 2002.

[6] W. Hartoyo, "Studi Perbandingan Berbagai Metode Analisa Kestabilan Lereng," Universitas Kristen Petra Surabaya, 1997. 